Egyptian Journal of Rabbit Science, 27 (2): 341- 358(2017)

\title{
EFFECT OF GARLIC (Allium sativum) TREATMENT ON HEMATOLOGICAL, BIOCHEMICAL, HORMONAL AND FERTILITY PARAMETERS OF MALE BOUSCAT RABBITS
}

\author{
H. M. El-Kelawy ${ }^{1}$; Merveet A.Mansour ${ }^{2}$, Randa E.El-Naggar ${ }^{2}$ and Nabila \\ E. M. Elkassas ${ }^{3}$ \\ ${ }^{1}$ Animal and Poultry Production Department,Faculty of Technology and \\ Development, Zagazig University \\ ${ }^{2}$ Zoology Department, Faculty of Science,Tanta University \\ ${ }^{3}$ Rabbit Production, Animal Production, Reserch Institute, Dokki-Giza
}

The present study was carried out on a flock of Bouscat rabbits belongs to El-Gemaiza Experimental Station, Animal Production Research Institute, Agriculture Research Center, Ministry of Agriculture, Egypt.

The experiment study lasted two months (from 6 up to 8 months of age) to investigate the effects of doses of garlic treatment on hematological, biochemical, hormonal and fertility parameters of male Bouscat rabbits. For this purpose, twenty four male Bouscat rabbits weighted 3150-3300 $\mathrm{g}$ were distributed into four experimental groups with equal number $(n=6)$. The first group was used as a control and subcutaneously injected with saline solution $(1 \mathrm{ml}$ of $0.9 \% \mathrm{NaCl})$, the second, third and fourth groups were subcutaneously injected once a week for 8 weeks with garlic 3, 9 and $27 \mathrm{mg} / \mathrm{kg}$ body weight, respectively.

Results showed that, the total numbers of RBCs and WBCs counts as well as $\mathrm{Hb}$ concentration in male rabbits treated with different doses of garlic (3, 9 or $27 \mathrm{mg} / \mathrm{kg}$ body weight, once a week for 8 weeks) were significantly $(P \leq 0.05$ or $P \leq 0.01)$ increased by increasing the dose of garlic. Lower dose of garlic (3 $\mathrm{mg} / \mathrm{kg}$ body weight) showed slight increases $(P \leq 0.05)$ in total protein and albumin levels and a slight decrease $(P \leq 0.05)$ in globulin level, the higher doses $(9$ and $27 \mathrm{mg} / \mathrm{kg}$ body weight) showed marked decreases $(P \leq 0.05)$ in total protein, albumin and globulin levels. The total lipid, total cholesterol and triglyceride levels in male rabbits treated with different doses of garlic were decreased by increasing the dose of garlic, this decrease was statistically significant $(P \leq 0.05$ or $P \leq 0.01)$ with the higher doses (9 and $27 \mathrm{mg} / \mathrm{kg}$ body weight). Garlic treatment to buck rabbits elicited a slight increase in high-density lipoprotein (HDL) level, while it showed marked decreases in low-density lipoprotein (LDL) and very low-density 
lipoprotein (VLDL) levels. The activity of AST enzyme for buck rabbits treated with different doses of garlic was insignificantly changed by increasing the dose of garlic. While, the lower dose of garlic $(3 \mathrm{mg} / \mathrm{kg}$ body weight) slightly decreased $(P \leq 0.05), A L T$ and ALP enzyme activities, the higher doses (9 and $27 \mathrm{mg} / \mathrm{kg}$ body weight) showed increases $(P \leq 0.05)$ in ALT and ALP enzyme activities of male rabbits. Treatment of buck rabbits with different doses of garlic slightly insignificantly decreased the urea level and slightly insignificantly increased creatinine level. Testosterone levels in rabbits treated with different doses of garlic were increased by increasing the dose of garlic, however, this increase was statistically significant $(P \leq 0.05)$ with the doses 9 and $27 \mathrm{mg} / \mathrm{kg}$. Lower dose of garlic (3 $\mathrm{mg} / \mathrm{kg}$ body weight) elicited increases in the ejaculate volume, concentration, the total output, the wave motions, the motility percentages, the percentages of live spermatozoa and the percentages of abnormal spermatozoa. However, the higher doses (9 and $27 \mathrm{mg} / \mathrm{kg}$ body weight) showed decreases in the ejaculate volumes, the wave motions and the motility percentages, but increased concentrations and abnormal spermatozoa.

Conclusively, it can be concluded that the lower doses of garlic can be safely used and improved fertility parameters of buck rabbits however, the higher doses may cause problems.

Key words: Garlic, blood hematological and biochemical, hormones, semen quality and buck rabbits

The potency of garlic has been acknowledged for over 5000 years. Garlic (Allium sativum), a member of the family Liliaceae, is a common food spice widely distributed and used all over the world as a condiment in various prepared food. Although there are many garlic supplements commercially available, they fall into one of four categories: fresh garlic, garlic oil, garlic powder and aged garlic extract (Tattelman, 2005).

Garlic contains more than 200 chemicals. It contains sulfur compounds (allicin, alliin and agoene), volatile oils, enzymes (allinase, peroxidase and miracynase), carbohydrates (sucrose and glucose), and minerals (selenium). It also contains amino acids (cysteine, glutamine, isoleucine and methionine), which help to protect cells from the harms of free radicals, bioflavonoids (quercetin and cyanidin, allistatin I and allistatin II and vitamins $\mathrm{C}$, E and A), which help to protect us from oxidation agents and free radicals (Ayaz and Alposy, 2007). 
Garlic and its constituents have been widely recognized as agents for prevention and treatment of cardiovascular diseases (Eilat-Adar et al., 2013), as well as for inhibition of tumors development, reduction of tumor mass and decrease the number of mitotic cells within tumors (Wallace et al., 2013). Previous studies have shown that garlic preparations possess many biological activities including antiparasitic (Salama et al., 2014), antifungal (Suleiman and Abdallah, 2014), antibacterial (Shaheen et al., 2015) and antioxidative (Asdaq, 2015) activities.

Garlic supplementation increased spermatogenesis and the quality of semen parameters in male rabbits (El-Amary and Abou-Warda, 2007). However, Hosseini and Khaki (2014) reported that garlic consumption decreased the quality of semen parameters in male rats. Concerning the male reproductive hormone (testosterone), dietary garlic increased testosterone level in male rats fed a high fatty diet (Omotoso et al., 2012). Other studies reported that garlic supplementation decreased testosterone level in male rats (Ebomoyi and Ahumibe, 2010).

The present study was designed to evaluate the effect of garlic treatment $(3,9$ and $27 \mathrm{mg} / \mathrm{kg}$ body weight injected subcutaneously once a week for 8 weeks) on physiological and reproductive parameters of buck Bouscat rabbits.

\section{MATERIALS AND METHODS}

The present study was carried out on a flock of Bouscat rabbits belongs to El-Gemaiza Experimental Station, Animal Production Research Institute, Agriculture Research Center, Ministry of Agriculture, Egypt.

The experiment study lasted two months (from 6 up to 8 months of age) to investigate the effects of garlic treatment on hematological, biochemical, hormonal and fertility parameters of male Bouscat rabbits. For this purpose, twenty four male Bouscat rabbits weighted 3150-3300 g were distributed into four experimental groups with equal number $(n=6)$. The first group was used as a control and subcutaneously injected with saline solution $(1 \mathrm{ml}$ of $0.9 \% \mathrm{NaCl})$, the second, third and fourth groups were subcutaneously injected with garlic 3, 9 and $27 \mathrm{mg} / \mathrm{kg}$ body weight, respectively. Garlic powder preparation, Tomex (ATOS Pharma, Cairo, Egypt) was dissolved in physiological saline, and doses of 3, 9 and 27 $\mathrm{mg} / \mathrm{kg}$ body weight were subcutaneously injected in the neck region of rabbits once a week for 8 weeks.

The bucks were housed separately in individual flat deck batteries (50 x 60 x $40 \mathrm{~cm}$ ) with universal specification, provided with galvanized feeders 
and automatic drinkers. All batteries were located in a naturally ventilated room. Buck rabbits were fed ad libitum a commercial pelleted ration containing $16.95 \%$ crude protein, 12.01 crude fibre and 2.77 fat and 7.95 ash. Clean fresh tape water was available at all the times ad libitum throughout the experimental period. All bucks were kept under the same managerial, hygienic and environmental conditions.

Blood samples $(5 \mathrm{ml} / \mathrm{each}$ rabbit) were collected from the ear vein of male rabbits. Each sample was divided into two tubes; the first was heparinized and the second was non-heparinized. The heparinized blood samples were used to test hematological parameters. Non-heparinized blood samples were immediately centrifuged at 3000 r.p.m. for 15 minutes and serum was separated, frozen under $-20^{\circ} \mathrm{C}$, and kept for biochemical and hormonal assessment. Red blood cells (RBCs), white blood cells (WBCs) counts and hemoglobin $(\mathrm{Hb})$ concentration were determined as described by Emad El-Eslam (1997).

Serum levels of total protein and albumen were determined according to Henry (1964) and Doumas et al. (1971), respectively, using commercial kits (Diamond diagnostics). The globulin value was obtained by subtracting the value of albumen from the corresponding value of total protein. Total lipid, high-density lipoprotein, low-density lipoprotein and very low-density lipoprotein levels were determined according to Zöllner and Kirsch (1962), while total cholesterol and triglyceride levels were determined according to Richmond (1973) and Fassati and Prencipe (1982), respectively, using commercial kits (Diamond diagnostics). The activity of aspartate aminotransferase (AST) and alanine amino-transferase (ALT) were assayed according to Reitman and Frankel (1957) and the activity of alkaline phosphate (ALP) was assayed according to Belfield and Goldberg (1971). Urea-N and creatinine levels were determined using commercial kits (Diamond diagnostics) according to the method of Patton and Crouch (1977) and Henry (1974), respectively.

Serum level of testosterone was measured using Coat-A-Count Total Testosterone (PITKTT-5, 2006-12-29) radioimmunoassay kits according to the method of Demetriou (1987). Serum level of tri-iodothyronine $\left(\mathrm{T}_{3}\right)$ was measured using Coat-A-Count Total $\mathrm{T}_{3}$ (PITKT3-7, 2009-07-16) radioimmunoassay kits according to the method of Hollander and Shenkman (1974). Serum level of thyroxine $\left(\mathrm{T}_{4}\right)$ was measured using Coat-A-Count Total $\mathrm{T}_{4}$ (PITKT4-4, 2006-03-18) radioimmunoassay kits according to the method of Albertini and Ekins (1982).

After four weeks of injection, semen samples were collected twice a week for four weeks using an artificial vagina device. Ejaculate volume, 
sperm concentration, total output, wave motion, sperm motility $\%$, live spermatozoa $\%$ and abnormal spermatozoa \% were estimated according to the procedures of El-Kelawy (1993).

Least Square Maximum Likelihood method of analysis (SPSS, 2004) was used to analyze the obtained data according to the following model:

$$
\text { Yij }=\mu+\mathrm{Ti}+\mathrm{eij}
$$

Where: Yij is any observation, $\mu$ is the overall mean of observation, Ti is the effect of treatment and eij is the random error.

Duncan's New Multiple Range test was used for multiple comparisons (Duncan, 1955).

\section{RESULTS AND DISCUSSION}

\section{Effect of garlic treatment on blood indices:}

Data in Table 1 showed that the total numbers of RBCs and WBCs counts as well as $\mathrm{Hb}$ concentration in male rabbits treated with different doses of garlic (3, 9 or $27 \mathrm{mg} / \mathrm{kg}$ body weight, once a week for 8 weeks) were significantly $(\mathrm{P} \leq 0.05$ or $\mathrm{P} \leq 0.01)$ increased by increasing the dose of garlic. The percentages of this increase reached 8.1, 24.6 and $38.9 \%$ for RBCs , 30.7, 37.7 and 79.4\% for WBCs and7.2, 24.2 and $38.5 \%$ for $\mathrm{Hb}$ as compared with that of the corresponding control value, respectively.

Garlic treatment increased the number of RBCs, WBCs counts and $\mathrm{Hb}$ concentration in male rabbits (Al-Jowari, 2014). Garlic significantly prevented the reduction of RBCs caused by lead intoxification (Ouarda and Abd-Ennour, 2011) in rabbits. However, Suleria et al. (2013b) reported that rabbits treated with garlic showed insignificant reduction in RBCs count. Fazlolahzadeh et al. (2011) suggested that garlic contains some constituents that may play a role in the function of organs related to blood cell formation such as thymus, spleen, and bone marrow to stimulate more blood production. In addition, Samson et al. (2012) suggested garlic compounds might have a stimulatory effect on some haematopoetic growth factors (cytokines) which interact with specific receptors on the surface of haematopoietic cells, regulating the proliferation and differentiation of progenitor cells and the maturation and functioning of mature cells. Chemical components of garlic seem to act as active oxygen scavenger competes with hemoglobin in the RBCs for oxygen resulting in tissue hypoxia, which in turn stimulates the kidney to form and secrete 
Table 1: Effect of garlic treatment on red blood cells (RBCs), white blood cells (WBCs) counts and hemoglobin $(\mathrm{Hb})$ concentration of male Bouscat rabbits.

\begin{tabular}{|c|c|c|c|c|c|c|}
\hline \multirow[b]{2}{*}{ Treatment } & \multicolumn{2}{|c|}{ RBCs } & \multicolumn{2}{|c|}{ WBCs } & \multicolumn{2}{|l|}{$\mathbf{H b}$} \\
\hline & $x 10^{6} / \mathrm{mm}^{3}$ & \begin{tabular}{|c|}
$\begin{array}{c}\text { \% of } \\
\text { change }\end{array}$ \\
\end{tabular} & $\mathrm{x} 10^{3} / \mathrm{mm}^{3}$ & $\begin{array}{c}\% \text { of } \\
\text { change }\end{array}$ & concentration & $\begin{array}{c}\% \text { of } \\
\text { change }\end{array}$ \\
\hline Control & $4.9^{b} \pm 0.5$ & - & $7.19^{c} \pm 0.3$ & - & $9.90^{\mathrm{b}} \pm 0.9$ & - \\
\hline Garlic(3 mg/kg) & $5.31^{\mathrm{ab}} \pm 0.7$ & 8.1 & $9.40^{b} \pm 0.4$ & 30.7 & $10.61^{\mathrm{ab}} \pm 0.7$ & 7.2 \\
\hline Garlic(9 mg/kg) & $6.12^{a} \pm 0.6$ & 24.6 & $9.90^{b} \pm 0.6$ & 37.7 & $12.30^{\mathrm{b}} \pm 0.9$ & 24.2 \\
\hline Garlic(27mg/kg) & $6.82^{a} \pm 0.5$ & 38.9 & $12.90^{\mathrm{a}} \pm 0.8$ & 79.4 & $13.7^{\mathrm{a}} \pm 0.8$ & 38.5 \\
\hline Significance & $*$ & - & $* *$ & - & $*$ & - \\
\hline
\end{tabular}

$\mathrm{a}, \mathrm{b}$ and $\mathrm{c}$ means with different super-script in the same column, differ significantly $P \leq 0.05$.

$*=P \leq 0.05$ and $* *=P \leq 0.01$.

erythropoietin. The end-product of metabolism of garlic in the body may also step up $\mathrm{Hb}$ synthesis and $\mathrm{RBC}$ production by their indirect effect on erythropoietin (Fazlolahzadeh et al., 2011). Also, garlic contain natural sulfur compounds which act as antioxidant active substances that implies the antioxidant action of garlic sulfhydryl groups on RBCs counts (Attia and Ali, 1993). Moreover, William (1999) reported that several vitamins like vitamin $\mathrm{B}_{1}, \mathrm{~B}_{2}, \mathrm{~B}_{6}, \mathrm{~B}_{9}, \mathrm{C}$ and $\mathrm{E}$ are present in garlic have a role in $\mathrm{RBCs}$ formation, maturation and in hemoglobin biosynthesis, absorption and utilization. Regarding effect of garlic on WBCs count, Onu and Aja (2011) reported garlic might help in boosting the immune system of the rabbits. Iranloye (2002) suggested the anti-infection properties of garlic that stimulate immune functions. Also, garlic possess some important phytochemicals such as flavonoids, steroidal glycosides, alkaloids, saponins, tannins, phenolics, pectin and amino acids, with their biological and physiological roles to stimulate the immune system and organs related to blood cell formation particularly the bone marrow (Jeorg and Lee, 1998).

\section{Effect of garlic treatment on serum protein fractions:}

The present study showed that the lower dose of garlic $(3 \mathrm{mg} / \mathrm{kg}$ body weight) showed slight increases $(\mathrm{P} \leq 0.05)$ in total protein and albumin levels and a slight decrease $(\mathrm{P} \leq 0.05)$ in globulin level, the higher doses $(9$ and $27 \mathrm{mg} / \mathrm{kg}$ body weight $)$ showed marked decreases $(\mathrm{P} \leq 0.05)$ in total protein, albumin and globulin levels (Table 2). The percentages of this change reached $10.8,-22.5$ and $-25.6 \%$ for total protein, $26.3,-13.2$ and $7.9 \%$ for albumin and $-8.5,-34.2$ and $-47.6 \%$ for globulin as compared with that of the corresponding control value, respectively. The $A / G$ ratios in male 
Table 2: Effect of garlic treatment on serum total protein, albumin (A) and globulin $(G)$ levels and albumin/globulin $(A / G)$ ratio of male Bouscat rabbits.

\begin{tabular}{|c|c|c|c|c|c|c|c|}
\hline \multirow{2}{*}{ Treatment } & \multicolumn{2}{|c|}{ Total protein } & \multicolumn{2}{|c|}{ Albumin (A) } & \multicolumn{2}{|c|}{ Globulin(G) } & \multirow{2}{*}{$\begin{array}{c}\text { A/G } \\
\text { Ratio }\end{array}$} \\
\hline & g/dl & $\begin{array}{c}\% \text { of } \\
\text { change }\end{array}$ & g/dl & $\begin{array}{c}\% \text { of } \\
\text { change }\end{array}$ & g/dl & $\begin{array}{c}\% \text { of } \\
\text { change }\end{array}$ & \\
\hline Control & $6.87^{\mathrm{a}} \pm 0.5$ & - & $3.80 \pm 0.5$ & - & $3.0^{\mathrm{a}} \pm 0.4$ & - & $1.24 \pm 0.4$ \\
\hline Garlic(3 mg/kg) & $7.61^{\mathrm{a}} \pm 0.7$ & 10.8 & $4.80 \pm 0.6$ & 26.3 & $2.81^{\mathrm{a}} \pm 0.5$ & -8.5 & $1.71 \pm 0.4$ \\
\hline Garlic(9 mg/kg) & $5.32^{b} \pm 0.5$ & -22.5 & $3.30 \pm 0.2$ & -13.2 & $2.02^{b} \pm 0.3$ & -34.2 & $1.63 \pm 0.2$ \\
\hline Garlic(27 mg/kg) & $5.11^{b} \pm 0.2$ & -25.6 & $3.50 \pm 0.3$ & -7.9 & $1.61^{b} \pm 0.2$ & -47.6 & $2.17 \pm 0.6$ \\
\hline Significance & $*$ & - & NS & - & $*$ & - & NS \\
\hline
\end{tabular}

a and $\mathrm{b}$ means with different super-script in the same column, differ significantly $(P \leq 0.05)$.

$*=P \leq 0.05$ and NS $=$ Not significant.

rabbits treated with different doses of garlic were insignificantly increased by increasing the dose of garlic.

Albumins and globulins are two key components of serum proteins. As albumin synthesizes in the liver, it can be used as a biomarker to monitor liver function (Friedman et al., 1980). Hussein et al. (2007) suggested that garlic has ability to stimulate the regeneration of hepatic tissue, which increases protein synthesis in damage liver, improves the functional status of the liver cells and prevent protein oxidation. In addition, it is believed that garlic affect whole body protein metabolism through hormonal regulation by stimulating adrenaline and nor-adrenaline hormonal secretion (Srivastava and Pathak, 2012b). On the other hand, the decrease in protein levels, observed with higher doses in the present investigation may be due to their degradation and possible utilization for metabolic purposes and may attributed to the destruction or necrosis of cells and their consequent impairment in protein synthesis machinery (Srivastava and Pathak, 2012b)

\section{Effect of garlic treatment on total lipid, total cholesterol and triglyceride} levels:

The present data in Table 3 showed that the total lipid, total cholesterol and triglyceride levels in male rabbits treated with different doses of garlic were decreased by increasing the dose of garlic, this decrease was statistically significant $(P \leq 0.05$ or $P \leq 0.01)$ with the higher doses $(9$ and $27 \mathrm{mg} / \mathrm{kg}$ body weight). The percentages of this decrease reached -23.4 , -51.0 and $-58.4 \%$ for the total lipid, $-3.6,-21.7$ and $-40.4 \%$ for cholesterol total cholesterol and $9.5,-29.8$ and $-37.1 \%$ for triglyceride as compared with that of the corresponding control value, respectively. 
Table 3: Effect of garlic treatment on serum total lipid, total cholesterol and triglyceride levels of male Bouscat rabbits.

\begin{tabular}{|l|c|c|c|c|c|c|}
\hline \multirow{2}{*}{ Treatment } & \multicolumn{2}{|c|}{ Total lipid } & \multicolumn{2}{c|}{ Total cholesterol } & \multicolumn{2}{c|}{ Triglyceride } \\
\cline { 2 - 7 } & $\mathbf{m g} / \mathbf{d l}$ & $\begin{array}{c}\text { \% of } \\
\text { change }\end{array}$ & $\mathbf{m g} / \mathbf{d l}$ & $\begin{array}{c}\text { \% of } \\
\text { change }\end{array}$ & mg/dl & $\begin{array}{c}\text { \% of } \\
\text { change }\end{array}$ \\
\hline Control & $195.64^{\mathrm{a}} \pm 19.1$ & - & $151.65^{\mathrm{a}} \pm 28.6$ & - & $127.34^{\mathrm{a}} \pm 8.2$ & - \\
\hline Garlic(3mg/kg) & $149.81^{\mathrm{b}} \pm 28.4$ & -23.4 & $146.14^{\mathrm{a}} \pm 13.6$ & -3.6 & $115.28^{\mathrm{a}} \pm 12.4$ & -9.5 \\
\hline Garlic(9mg/kg) & $95.82^{\mathrm{c}} \pm 16.1$ & -51.0 & $118.72^{\mathrm{b}} \pm 17.9$ & -21.7 & $89.34^{\mathrm{b}} \pm 15.6$ & -29.8 \\
\hline Garlic(27mg/kg) & $81.43^{\mathrm{c}} \pm 15.3$ & -58.4 & $90.44^{\mathrm{c}} \pm 12.5$ & -40.4 & $80.14^{\mathrm{b}} \pm 17.4$ & -37.1 \\
\hline Significance & $* *$ & - & $* *$ & - & $*$ & - \\
\hline
\end{tabular}

a, b and c Means with different super-script in the same column, differ significantly ( $P \leq 0.05)$.

$*=P \leq 0.05$ and $* *=P \leq 0.01$.

Addition of garlic extract to oxidated vegetable oil caused a significant reduction in total cholesterol and triglyceride levels in rabbits (Fiolka et al., 2004). Garlic supplementation also elicited a decrease in total cholesterol and triglyceride levels in rabbits (Suleria et al., 2013a) . In addition, garlic administration reduced serum total cholesterol and triglyceride levels in hypercholesterolemic rabbits (Fyiad and El-Sayed, 2012). Moreover, garlic administration decreased the levels of total cholesterol and triglyceride in diabetic rabbits (Rind et al., 2013). These compounds may exert their anti-cholesterolemic effect by three different mechanisms: by inhibiting hepatic cholesterol biosynthesis (Singh and Porter, 2006); by enhancing cholesterol turnover to bile acids and its excretion through gastrointestinal tract (Srinivasan and Sambaiah, 1991); or by inhibiting cholesterol absorption from intestinal lumen (Slowing et al., 2001). Moreover, other non-sulphur components of garlic, such as steroid saponins, might also be able to reduce lipids and cholesterol biosynthesis (Omojola et al., 2009).

Effect of garlic treatment on high-density lipoprotein (HDL), low-density lipoprotein (LDL) and very low-density lipoprotein (VLDL) levels:

Results showed that garlic treatment to male rabbits elicited a slight increase in high-density lipoprotein (HDL) level, while it showed marked decreases in low-density lipoprotein (LDL) and very low-density lipoprotein (VLDL) levels (Table 4). The percentages of this increase reached 12.7, 2.0 and $8.7 \%$ for(HDL), $-13.1,-31.4$ and $-66.4 \%$ for (LDL) and $-9.3,-29.7$ and $-37.1 \%$ for(VLDL) as compared with that of the corresponding control value, respectively.

Results are consistent with the results of Fiolka et al. (2004) who reported adding garlic extract to oxidized rapeseed oil caused a significant 
Table 4: Effect of garlic treatment on serum high-density lipoprotein (HDL), low-density lipoprotein (LDL) and very low-density lipoprotein (VLDL) levels of male Bouscat rabbits.

\begin{tabular}{|l|c|c|c|c|c|c|}
\hline \multirow{2}{*}{ Treatment } & \multicolumn{2}{|c|}{ HDL } & \multicolumn{2}{c|}{ LDL } & \multicolumn{2}{c|}{ VLDL } \\
\cline { 2 - 7 } & $\mathbf{m g} / \mathbf{d l}$ & $\begin{array}{c}\text { \% of } \\
\text { change }\end{array}$ & mg/dl & $\begin{array}{c}\text { \% of } \\
\text { change }\end{array}$ & mg/dl & $\begin{array}{c}\text { \% of } \\
\text { change }\end{array}$ \\
\hline Control & $42.71 \pm 5.2$ & - & $83.47^{\mathrm{a}} \pm 6.9$ & - & $25.47^{\mathrm{a}} \pm 1.6$ & - \\
\hline Garlic(3 $\mathbf{~ m g / k g ) ~}$ & $48.15 \pm 3.3$ & 12.7 & $72.5^{\mathrm{ab}} \pm 9.1$ & -13.1 & $23.1^{\mathrm{a}} \pm 4.1$ & -9.3 \\
\hline Garlic (9 mg/kg) & $43.57 \pm 5.0$ & 2.0 & $57.28^{\mathrm{b}} \pm 12.9$ & -31.4 & $17.9^{\mathrm{b}} \pm 3.1$ & -29.7 \\
\hline Garlic(27 mg/kg) & $46.41 \pm 4.2$ & 8.7 & $28.02^{\mathrm{c}} \pm 5.1$ & -66.4 & $16.03^{\mathrm{b}} \pm 5.5$ & -37.1 \\
\hline Significance & $\mathrm{NS}$ & - & $* *$ & - & $*$ & - \\
\hline
\end{tabular}

$\mathrm{a}, \mathrm{b}$ and c Means with different super-script in the same column, differ significantly $(P \leq 0.05)$.

$*=P \leq 0.05, * *=P \leq 0.01$ and $\mathrm{NS}=$ Not significant.

increase the level of HDL in rabbit. Treatment with different doses of aqueous garlic extracts also caused a reduction in LDL and VLDL levels and increased the level of HDL in rabbits (Suleria et al., 2013a). Different studies reported that garlic and its constituents decreased LDL and increased HDL levels in hyperlipidemic rabbits (Fyiad and El-Sayed, 2012).The protective effects of garlic may be attributed to inhibition of enzymes involved in lipid synthesis, prevention of lipid peroxidation and LDL, and increasing antioxidant activity (Rahman and Lowe, 2006). Dillon et al. (2003) reported that garlic inhibits the in vitro oxidation of isolated human LDL by scavenging superoxide and inhibiting the formation of lipid peroxides; and protects cellular structures against peroxidation, which act as inhibitors for some enzymes, such as hydroxyl methyl glutaryl CoA reductase (Ashraf et al., 2005). Moreover, garlic appears to inhibit hepatic fatty acid synthesis by lowering key enzymes activities in supplying substrates, and to prevent lipid implantation on the arterial wall (Abramovitz et al., 1999). The hypolipidaemic activities of garlic may be also attributed to other non-sulphur components, like the steroid saponins (Omojola et al., 2009).

\section{Effect of garlic treatment on serum enzyme activities of the liver:}

The activity of AST enzyme in male rabbits treated with different doses of garlic was insignificantly changed by increasing the dose of garlic (Table 5). While, the lower dose of garlic ( $3 \mathrm{mg} / \mathrm{kg}$ body weight) slightly decreased $(P \leq 0.05)$, ALT and ALP enzyme activities, the higher doses $(9$ and $27 \mathrm{mg} / \mathrm{kg}$ body weight $)$ showed increases $(P \leq 0.05)$ in ALT and ALP 
Table 5: Effect of garlic treatment on serum aspartate amino-transferase (AST), alanine amino-transferase (ALT) and alkaline phosphatase (ALP) enzyme activities of male Bouscat rabbit.

\begin{tabular}{|l|c|c|c|c|c|c|}
\hline \multirow{2}{*}{ Treatment } & \multicolumn{2}{|c|}{ AST } & \multicolumn{2}{c|}{ ALT } & \multicolumn{2}{c|}{ ALP } \\
\cline { 2 - 7 } & IU/L & $\begin{array}{c}\text { \% of } \\
\text { change }\end{array}$ & IU/L & $\begin{array}{c}\text { \% of } \\
\text { change }\end{array}$ & IU/L & $\begin{array}{c}\text { \% of } \\
\text { change }\end{array}$ \\
\hline Control & $79.80 \pm 7.4$ & - & $28.07^{\mathrm{b}} \pm 3.6$ & - & $19.30^{\mathrm{b}} \pm 3.4$ & - \\
\hline Garlic (3 mg/kg) & $75.10 \pm 8.2$ & -5.9 & $24.70^{\mathrm{b}} \pm 4.1$ & -12.0 & $13.80^{\mathrm{b}} \pm 3.5$ & -28.5 \\
\hline Garlic (9 mg/kg) & $81.10 \pm 7.2$ & 1.6 & $32.05^{\mathrm{ab}} \pm 4.5$ & 14.2 & $21.40^{\mathrm{b}} \pm 3.3$ & 10.9 \\
\hline Garlic (27 mg/kg) & $84.10 \pm 8.8$ & 5.3 & $35.90^{\mathrm{a}} \pm 4.1$ & 27.9 & $27.09^{\mathrm{a}} \pm 3.7$ & 40.4 \\
\hline Significance & $\mathrm{NS}$ & - & $*$ & - & $*$ & - \\
\hline
\end{tabular}

a and b means with different super-script in the same column, differ significantly $(P \leq 0.05)$.

$*=P \leq 0.05$ and NS = Not significant.

enzyme activities of male rabbits. The percentages of this change reached 5.9, 1.6 and 5.3\% for AST, -12.0, 14.2 and 27.9\% for ALT and -28.5, 10.9 and $40.4 \%$ for ALP in comparison with that of the control value, respectively.

Abd and Al-Baghdadi (2009) reported that administration of aqueous garlic extract restored AST and ALT enzymes activities induced by carbon tetrachloride in male rabbits. Aletan and Eteng (2013) also reported that oral administration of garlic extract increased AST enzyme activity by increasing the doses in rats. Ajayi and Ajayi (2014) reported that AST and ALP enzyme activities were decreased with lower dose of garlic powder, but increased with higher dose in hypercholesterolemic rats.

\section{Effect of garlic treatment on kidney function:}

Results in Table (6) showed that treatment of male rabbits with different doses of garlic slightly insignificantly decreased the urea level and slightly insignificantly increased creatinine level. The percentages of this increase reached-4.5, -10.9 and $-0.4 \%$ for urea level and 4.9, 2.4 and $12.2 \%$ for creatinine level as compared with that of the corresponding control value, respectively. Administration of garlic extract decreased the levels of urea and creatinine in diabetic rabbits (Rind et al., 2013) or normal rabbits (Suleria et al., 2013b).On the other hand, Mahmoodi et al. (2006) found that administration of raw garlic did not change urea and creatinine levels in human. Omurtag et al. (2005) reported that garlic and its components provide protection against free radical damage in the body through their antioxidant activities. The antioxidative activities of garlic could also be 
Table 6: Effect of garlic treatment on serum urea and creatinine levels of male Bouscat rabbits.

\begin{tabular}{|l|c|c|c|c|}
\hline \multirow{2}{*}{ Treatment } & \multicolumn{2}{|c|}{ Urea } & \multicolumn{2}{c|}{ Creatinine } \\
\cline { 2 - 5 } & $\mathbf{m g} / \mathbf{d l}$ & \% of change & $\mathbf{~ m g / d l}$ & \% of change \\
\hline Control & $31.20 \pm 3.9$ & - & $0.41 \pm 0.3$ & - \\
\hline Garlic (3 mg/kg) & $29.80 \pm 2.2$ & -4.5 & $0.43 \pm 0.3$ & 4.9 \\
\hline Garlic (9 mg/kg) & $27.80 \pm 1.9$ & -10.9 & $0.42 \pm 0.2$ & 2.4 \\
\hline Garlic (27 mg/kg) & $31.08 \pm 0.6$ & -0.4 & $0.46 \pm 0.1$ & 12.2 \\
\hline Significance & NS & - & NS & - \\
\hline
\end{tabular}

NS = Not significant).

related to its contents of cysteine-containing bioactive compounds, selenocompounds and flavonoids (Banerjee and Maulik, 2002).

\section{Effect of garlic treatment on testosterone hormone level:}

Testosterone levels in rabbits treated with different doses of garlic were increased by increasing the dose of garlic (Table 7). However, this increase was statistically significant $(P \leq 0.05)$ with the doses 9 and 27 $\mathrm{mg} / \mathrm{kg}$ body weight. The percentages of this increase reached 12.5, 27.4 and $24.7 \%$ as compared with that of the corresponding control value, respectively. Testosterone hormone was significantly higher in garlic-fed male rabbit (El-Amary and Abou-Warda, 2007). El-Shafey et al. (2009) attributed the garlic-induced increase in testosterone level to the elevation of sex hormone binding globulin, which binds more testosterone, and consequently, oblige the testis to excrete more male sex hormone in plasma. Oi et al. (2001) suggested that garlic supplementation might enhance protein anabolism and suppress protein catabolism due to hormonal regulation by the stimulation of steroid hormones, leading to greater testis testosterone content and lower plasma corticosterone concentration. Mirfardi and Johari, (2015) suggested that garlic compounds are responsible for the significant increase in testosterone levels by affecting the performance of steroidgenerating enzymes, testosterone hormone and its metabolites. They concluded that garlic supplementation likely increases testicular testosterone content due to the stimulation of LH secretion from the pituitary gland, which stimulate the testes to increase its testosterone production.

\section{Effect of garlic treatment on physical semen characteristics:}

The present study showed that the lower dose of garlic $(3 \mathrm{mg} / \mathrm{kg}$ body weight) elicited increases in the ejaculate volume, concentration, the total output, the wave motions, the motility percentages, the percentages of live spermatozoa and the percentages of abnormal spermatozoa (Table 8). 
Table 7: Effect of garlic treatment on testosterone level of male Bouscat rabbits.

\begin{tabular}{|l|c|c|}
\hline \multirow{2}{*}{ Treatment } & \multicolumn{2}{|c|}{ Testosterone } \\
\cline { 2 - 3 } & ng/dl & \% of change \\
\hline Control & $4.01^{\mathrm{b}} \pm 0.3$ & - \\
\hline Garlic $(3 \mathrm{mg} / \mathrm{kg})$ & $4.51^{\mathrm{b}} \pm 0.3$ & 12.5 \\
\hline Garlic $(9 \mathrm{mg} / \mathrm{kg})$ & $5.11^{\mathrm{a}} \pm 0.4$ & 27.4 \\
\hline Garlic $(27 \mathrm{mg} / \mathrm{kg})$ & $5.00^{\mathrm{a}} \pm 0.4$ & 24.7 \\
\hline Significance & $*$ & - \\
\hline
\end{tabular}

$\mathrm{a}$ and $\mathrm{b}$ Means with different super-script in the same column, differ significantly $(P \leq$ $0.05)$.

$*=P \leq 0.05$.

Table 8: Effect of garlic treatment on physical semen characteristics including ejaculated volume of semen, concentration and total output of sperm of male Bouscat rabbits.

\begin{tabular}{|c|c|c|c|c|c|c|c|}
\hline Treatment & $\begin{array}{c}\text { Ejaculate } \\
\text { volume } \\
(\mathrm{ml})\end{array}$ & $\begin{array}{c}\text { Concentration } \\
\left(\mathbf{x 1 0 ^ { 6 }} / \mathbf{m l}\right)\end{array}$ & $\begin{array}{c}\text { Total output } \\
\left(\times 10^{6}\right)\end{array}$ & $\begin{array}{c}\text { Wave } \\
\text { motion } \\
\text { ( Score) }\end{array}$ & $\begin{array}{c}\text { Motility } \\
(\%)\end{array}$ & $\begin{array}{c}\text { Live sperm } \\
(\%)\end{array}$ & $\begin{array}{c}\text { Abnormal } \\
\text { sperm } \\
(\%)\end{array}$ \\
\hline Control & $0.71 \pm 0.1$ & $1.99^{b} \pm 0.5$ & $1.4^{\mathrm{b}} \pm 0.4$ & $3.40 \pm 0.3$ & $68.32 \pm 4.8$ & $93.83 \pm 1.1$ & $4.01^{b} \pm 0.5$ \\
\hline $\begin{array}{l}\text { Garlic } \\
\mathrm{mg} / \mathrm{kg})\end{array}$ & $0.83 \pm 0.1$ & $3.55^{\mathrm{a}} \pm 0.7$ & $2.57^{\mathrm{a}} \pm 0.5$ & $3.90 \pm 0.2$ & $73.37 \pm 5.3$ & $94.67 \pm 0.6$ & $4.11^{\mathrm{b}} \pm 0.3$ \\
\hline $\begin{array}{l}\text { Garlic } \\
\mathrm{mg} / \mathrm{kg})\end{array}$ & $0.61 \pm 0.1$ & $3.29^{\mathrm{a}} \pm 0.4$ & $2.01^{\mathrm{b}} \pm 0.3$ & $3.35 \pm 0.3$ & $67.52 \pm 4.2$ & $93.50 \pm 1.0$ & $4.51 \pm 0.6$ \\
\hline $\begin{array}{ll}\text { Garlic } & (27 \\
\mathrm{mg} / \mathrm{kg}) & \end{array}$ & $0.52 \pm 0.1$ & $1.95^{\mathrm{b}} \pm 0.5$ & $1.03^{\mathrm{b}} \pm 0.2$ & $2.90 \pm 0.3$ & $59.17 \pm 3.6$ & $92.17 \pm 0.8$ & $5.41^{\mathrm{a}} \pm 0.4$ \\
\hline Significance & NS & $*$ & $*$ & NS & NS & NS & $*$ \\
\hline
\end{tabular}

$\mathrm{a}$ and $\mathrm{b}$ means with different super-script in the same column, differ significantly $(P \leq 0.05)$.

$*=P \leq 0.05$ and NS $=$ Not significant.

On the other hand, the higher doses ( 9 and $27 \mathrm{mg} / \mathrm{kg}$ body weight) showed decreases in the ejaculate volumes, the wave motions and the motility percentages, but increased concentrations and abnormal spermatozoa. These results are in good accordance with the results of ElAmary and Abou-Warda (2007) who found that quality of semen parameters was significantly higher after adding garlic to male rabbit diets. The present results are also consistent with the results of Ouarda and Abd-Ennour (2011) who found that treatment of rabbits with row garlic restored lead-induced decrease in sperm speed, motility and viability.

Conclusively, the present study confirms the health and medicinal benefits of garlic. The dose of garlic plays a key role in determining, which effect its administration would have on the physiology and biochemistry of 
the body organs. While the lower doses of garlic can be safely used, the higher doses may cause problems. The lower dose of garlic improved fertility parameters of buck rabbits.

\section{REFERENCES}

Abd, A.J. and Al-Baghdadi, R.J. (2009): Effects of garlic oil in correction of hepatotoxicity induced by $\mathrm{CCl}_{4}$ in rabbits. Al-Anbar J. Vet. Sci., 2(2): 7-13.

Abramovitz, D.; Gavri, S. and Harats, D. (1999): Allicin induced decrease in formation of fatty streaks (athesosclerosis) in mice fed a cholesterol rich diet. Coronary Artery Disease, 10: 515-519.

Ajayi, O.B. and Ajayi, D.D. (2014): Effect of dry garlic powder on plasma lipid profile and enzyme activities in some tissues of hypercholesterolemic rats. Adv. Biochem., 2(3): 45-49.

Albertini, A. and Ekins, R. (1982): Free $T_{4}$ and free $T_{3}$ measurement in patients with anti-iodothyronine autoantibodies. In: Free Hormones in Blood. Elsevier Biomedical Press, Amsterdam, pp: 231-238.

Aletan, U.I. and Eteng, M.U. (2013): Effect of the oral administration of Allium cepa and Allium sativum on some serum enzymes of normal and iodine treated albino wistar rats. Ann. Biol. Res., 4(1): 226-231.

Al-Jowari, S.A. (2014): Effect of garlic powder (Allium sativum) on blood constituents in male rabbits. J. Al-Nahrain Univ., 17 (3): 132-137.

Asdaq, S.M.B. (2015): Antioxidant and hypolipidemic potential of aged garlic extract and its constituent, S-Allyl Cysteine, in rats. Evid. Based Complement. Alternat. Med., 2015: 1-7.

Ashraf, R.; Aamir, K.; Shaikh, A.R. and Ahmed, T. (2005): Effects of garlic on dyslipidemia in patients with type 2 Diabetes mellitus. J. Ayub Med. Coll. Abbottabad, 17(3): 1-5.

Attia, M.H. and Ali, S.H. (1993): Natural sulfur compounds as anti-lead active substances. Egypt. J. Med. Sci., 14: 327-334.

Ayaz, E. and Alposy, H.C. (2007): Garlic (Allium sativum) and traditional medicine. Turk. Parazitol. Derg., 31(2): 145-149.

Banerjee, S.K. and Maulik, S.K. (2002): Effect of garlic on cardiovascular disorders: a review. Nutr. J., 1: 4-17.

Banerjee, S.K.; Maulik, M.; Manchanda, S.C.; Dinda, A.K.; Das, T.K. and Maulik, S.K. (2001): Garlic-induced alteration in rat liver and kidney morphology and associated changes in endogenous antioxidant status. Food Chem. Toxicol., 39: 793-797. 
Belfield, A. and Goldberg, D.M. (1971): Colorimetric determination of alkaline phosphatase. Enzyme, 12: 561-568.

Demetriou, J.A. (1987): Testosterone. In: Pesce L.A. and Kaplan L.A., Editors. Methods in Clinical Chemistry. St Louis. The C.V. Mosby Company.

Dillon, S.A.; Burmi, R.S.; Lowe, G.M.; Billington, D. and Rahman, K. (2003): Antioxidant properties of aged garlic extract: An in vitro study incorporating human low-density protein. Life Sci., 72: 1583-1594.

Doumas, B.T.; Watson, W.A. and Biggs, H.G. (1971): Albumin standards and measurement of serum albumin with bromcresol green. Clin. Chim. Acta., 31(1): 87-96.

Duncan, D.B. (1955): Multiple range and multiple F tests. Biometrics, 11: $1-42$.

Ebomoyi, M.I. and Ahumibe, K.C. (2010): Serum testosterone and morphology of the testes in Wistar rats following chronic garlic feeding. J. Phys. Pathophys., 1(3): 39-43.

Eilat-Adar, S.; Sinai, T.; Yosefy, C. and Henkin, Y. (2013): Nutritional recommendations for cardiovascular disease prevention. Nutr., 5(9): 3646-3683.

El-Amary, H.H. and Abou-Warda, M.A. (2007): Effect of different levels of garlic and leek as additives to rabbit rations on production and reproductive performance. J. Agric. Sci. Mansoura Univ., 32 (12): 9832-9843.

El-Kelawy, H.M. (1993): Studies on reproductive and productive performance in rabbits. Ph.D. Thesis, Faculty of Agriculture, Zagazig University, Egypt.

El-Shafey, A.A.; Ali, E.A. and Mazrook, E.A. (2009): Effect of garlic oil on hematological parameters, blood respiratory function and serum testosterone in male rat's exposure to an electromagnetic field. Isotope Rad. Res., 41(2): 397-410.

Emad El-Eslam, A.T. (1997): Physiological Studies on Nigella sativa Seed. M.Sc. Thesis, Faculty of Agriculture, Alexandria University, Egypt.

Fassati, P. and Prencipe, L. (1982): Serum triglycerides determined colorimetrically with an enzyme that produces hydrogen peroxide. Clin. Chem., 28: 2077-2080.

Fazlolahzadeh, F.; Keramati, K.; Nazifi, S.; Shirian, S. and Seifi, S. (2011): Effect of garlic (Allium sativum) on hematological parameters and plasma activities of ALT and AST of rainbow trout in temperature stress. Austr. J. Bas. Appl. Sci., 5(9): 84-90. 
Fiolka, J.Z.; Kasperczyk, S.; Kasperczyk, A.; Birkner, E.; Mamczar, E.G.; Pita, B.S. and Schneider, A. (2004): Influence of oxidated vegetable oil and garlic extract upon the development of experimental atherosclerosis in rabbits. Bull. Vet. Inst. Pulawy., 48: 453-459.

Friedman, R.B.; Anderson, R.E.; Entine, S.M. and Hirshberg, S. (1980): Effects of diseases on clinical laboratory test. Clin. Chem., 6: 476.

Fyiad, A.A. and El-Sayed, S.T. (2012): Effect of Allium sativum extract on serum lipid and antioxidant status in hypercholesterolemic rabbits. Life Sci. J., 9(3): 187:196.

Henry, R.J. (1964): Colorimetric Determination of Total Protein. Clinical Chemistry. Harper and Row Publishers, New York, pp: 181.

Hollander, C.S. and Shenkman, L. (1974): Radioimmunoassay for Triiodothyronine and Thyroxine In: Rothfeld, B. editor. Nuclear Medicine In Vitro, Philadelphia: Lippincott., 136-149.

Hosseini, N. and Khaki, A. (2014): Effect of aqueous extract of garlic (Allium sativum) on sperms morphology, motility, concentration and its antioxidant activity in rats. Afinidad. Org., 80(566): 201-204.

Hussein, J.S.; Oraby, F.S. and El-Shafey, N. (2007): Antihepatotoxic effect of garlic and onion oils on Ethanol-induced liver injury in rats. $J$. Appl. Sci. Res., 3(11): 1527-1533.

Jeorg, H.G. and Lee, Y.W. (1998): Protective effect of daily sulphide on $\mathrm{N}$-nitrosodimethylamine-induced immunosuppression in mice. Cancer Letts., (11): 73-79.

Mahmoodi, M.; Islami, M.R.; Karam, A.G.; Khaksari, M.; Lotfi, A.S.; Hajizadeh, M.R. and Mirzaee, M.R. (2006): Study of the effects of raw garlic consumption on the level of lipids and other blood biochemical factors in hyperlipidemic individuals. Pak. J. Pharm. Sci., 19(4): 295-298.

Oi, Y.; uri, k.; Imafuku, M.; Shishido, C.; Kominato, Y.; Nishimura, S. and Iwai, K. (2001): Garlic supplementation increases testicular testosterone and decreased plasma corticosterone in rats fed a high protein diet. J. Nutr., 131: 2150-2156.

Omojola, A.B.; Fagbuaro, S.S. and Ayen, A.A. (2009): Cholesterol content, physical and sensory properties of pork from pigs fed varying levels of dietary garlic (Allium sativum). World Appl. Sci. J., 6(7): 971975.

Omotoso, G.O.; Jimoh, A.A.G.; Olawuyi, T.S.; Olorunfemi, O.J.; Oyewopo, A.A.; George, O.S. and Alabi, A.S. (2012): Evaluation of sex hormones of male rats treated with garlic aqueous extracts and high fatty diet. West Afr. J. Assisted Reprod., 2(1): 20-23. 
Omurtag, G.Z.; Guranlioglu, F.D. and Sehirli, O. (2005): Protective effect of aqueous garlic extract against naphthalene-induced oxidative stress in mice. J. Pharm. Pharmacol., 57: 623-630.

Onu, P.N. and Aja, P.M. (2011): Growth performance and haematological indices of weaned rabbits fed garlic (Allium sativum) and ginger (Zingiber officinale) supplemented diets. Int. J. Food Agri. Vet. Sci., 1(1): 51-59.

Patton, C.J. and Crouch, S.R. (1977): Calorimetric determination of serum urea. Anal. Chem., 49: 464-469.

Rahman, K. and Lowe, G. (2006): Garlic and cardiovascular disease: A critical review. J. Nutr., 136: 736-740.

Reitman, S. and Frankel, S. (1957): Colorimetric method for the determination of serum glutamic oxalacetic and glutamic pyruvic transaminases. Am. J. Clin. Pathol., 28: 56-63.

Richmond, W. (1973): Preparation and properties of a cholesterol oxidase from Nocardia $s p$. and its application to the enzymatic assay of total cholesterol in serum. Clin. Chem., 19: 1350-1356.

Rind, A.N.; Dahot, M.U.; Malik, S.A.; Kumar, M.; Bhutto, M.A. and Rafiq, M. (2013): Comparative antihyperglycemic activity of aqueous extracts of garlic (Allium sativum) and ginger (Zingiber officinale) in alloxan-induced male rabbits. Pak. J. Biotechnol., 10(2): 53-62.

Salama, A.A.; AbouLaila, M.; Terkawi, M.A.; Mousa, A.; El-Sify, A.; Allaam, M.; Zaghawa, A.; Yokoyama, N. and Igarashi, A. (2014): Inhibitory effect of allicin on the growth of Babesia and Theileria equi parasites. Parasitol. Res., 113(1): 275-283.

Samson, E.S.; Olasunkanmi, A.K.; Joel, J.S. and Alfred, F.E. (2012): Haematological and hepatotoxic potential of onion (Allium cepa) and garlic (Allium sativum) extracts in rats. Eur. J. Med. Plants, 2(4): 290307.

Shaheen, A.Y.; Sheikh, A.A.; Rabbani, M.; Aslam, A.; Bibi, T.; Liaqat, F.; Muhammad, J. and Rehmani, S.F. (2015): Antibacterial activity of herbal extracts against multi-drug resistant Escherichia coli recovered from retail chicken meat. Pak. J. Pharm. Sci., 28(4): 1295-1300.

Singh, D.K. and Porter, T.D. (2006): Inhibition of sterol 4 alpha-methyl oxidase is the principal mechanism by which garlic decreases cholesterol synthesis. J. Nutr., 136(3): 759-764.

Slowing, K.; Ganado, P.; Anz, M.; Ruiz, E. and Tejerina, T. (2001): Study of garlic extracts and fractions on cholesterol plasma levels and vascular reactivity in cholesterol-fed rats. J. Nutr. Sci., 131: 994-999.

SPSS (2004). Statistics Users Guide, Version 10, SPSS Inc., USA. 
Srinivasan, K. and Sambaiah, K. (1991): The effect of spices on cholesterol $7 \alpha$-hydroxylase activity and on serum and hepatic cholesterol levels in the rat. Int. J. Vit. Nutr. Res., 61: 364-369.

Srivastava, S. and Pathak, P.H. (2012): Garlic (Allium sativum) extract supplementation alters the glycogen deposition in liver and protein metabolism in gonads of female albino rats. Int. J. Pharm. Sci. Drug Res., 4(2): 126-129.

Suleiman, E.A. and Abdallah, W.B. (2014): In vitro activity of garlic (Allium sativum) on some pathogenic fungi. Eur. J. Med. Plants, 4(10): 1240-1250.

Suleria, H.A.R.; Butt, M.S.; Anjum, F.M.; Ashraf, M.; Qayyum, M.M.N.; Khalid, N. and Younis, M.S. (2013a): Aqueous garlic extract attenuates hypercholesterolemic and hyperglycemic perspectives; Rabbit experimental modeling. J. Med. Plants Res., 7(23): 1709-1717.

Suleria, H.A.R.; Butt, M.S.; Anjum, F.M.; Sultan, S. and Khalid, N. (2013b): Aqueous garlic extract; Natural remedy to improve haematological, renal and liver status. J. Nut. Food Sci., 4: 252-258.

Tattelman, E. (2005): Health effect of garlic. Am. Fam. Physician, 72: 103106.

Wallace, G.C.; Haar, C.P.; Vandergrift, W.A.; Giglio, P.; Dixon-Mah, Y.N.; Varma, A.K.; Ray, S.K.; Patel, S.J.; Banik, N.L. and Das, A. (2013): Multitargeted DATS prevents tumor progression and promotes apoptosis in ectopic glioblastoma xenografts in SCID mice via HDAC inhibition. J. Neurooncol, 114: 43-50.

William, H.C. (1999): Organic Minerals for Pigs. Biotech. Feed Industry, Proc. $15^{\text {th }}$ Ann. Symp. pp. 51, Nottingham Univ. press, Nottingham, Leics, UK.

Zöllner, N. and Kirsch, K. (1962): Uber die quantitative Bestimmung von Lipoiden (Mikrome thode) mittels dervielen natiirlichen Lipoiden (allen bek annten Plasmali-poiden) geme in samen Sulphophosphovanill in Reaktion. Z. Ges. Exp. Med., 135(6): 545-561. 


\title{
الملخص العربي \\ تأثير المعاملة بالثوم علي التركيب الكيمائي للام والهرمونات وقياسات الخصوبة في ذكور الأرانب البوسكات
}

\author{
حسن محمود الكيلاوى ، ميرفيت أنور منصور، راندا عز الدين النجار، نبيلة السيد محمود

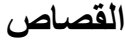 \\ قسم الإنتاج الحيو اني و الداجني ـ كلية التكنولوجيا والتتمية- جامعة الزقازيق

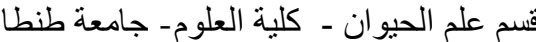 \\ قسم بحوث تربية الأرانب ـ معهد بحوث الإنتاج الحيو اني الدقي ـ الجيزة
}

أجريت هذه الدراسة على قطيع من أر انب البوسكات بمحطة بحوث الجميزة، معهذ بحوث الإنتاج

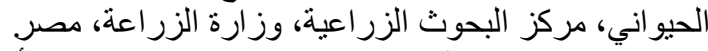

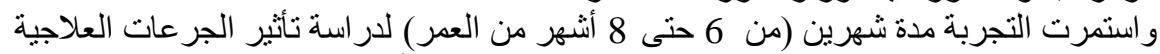

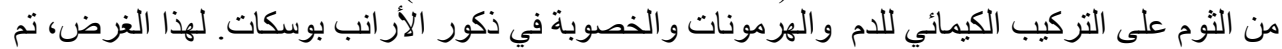

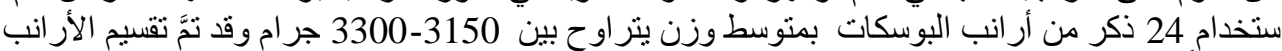

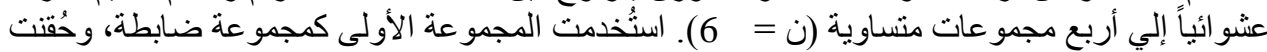

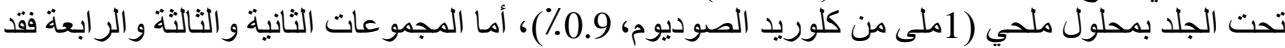

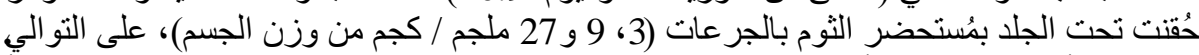

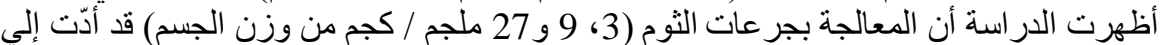

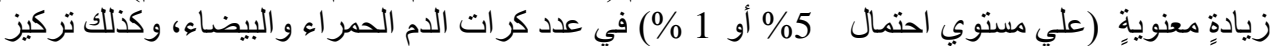
الهيموجلوبين بزيادة الجر عة المُّتخدمة.

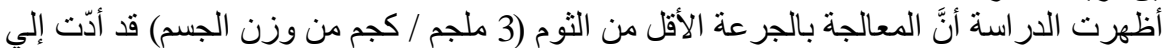

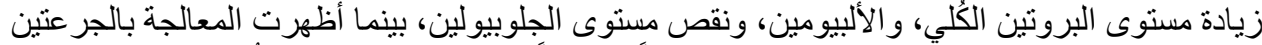

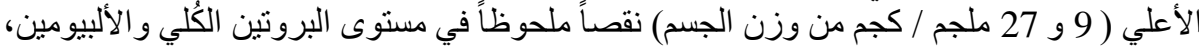

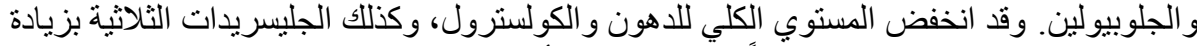

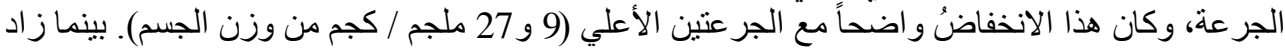

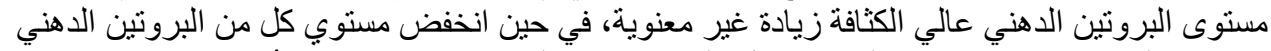

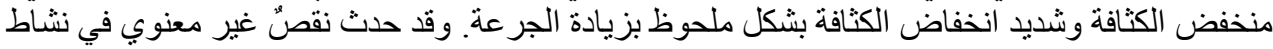

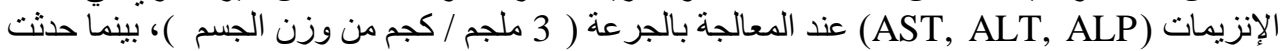

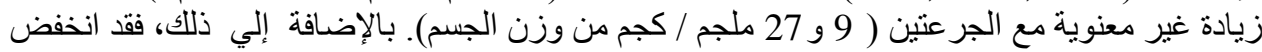

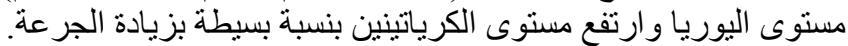

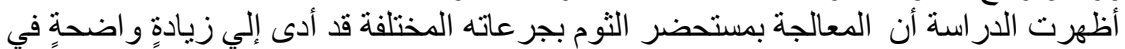

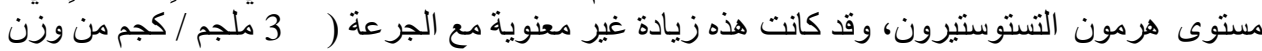

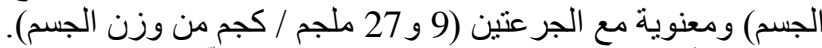

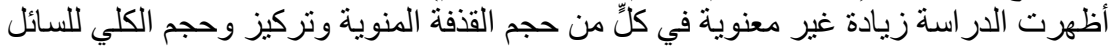

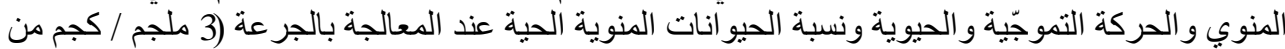

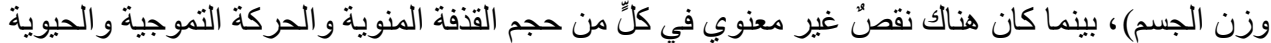

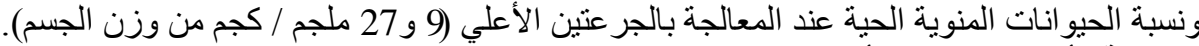

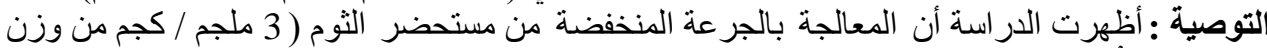

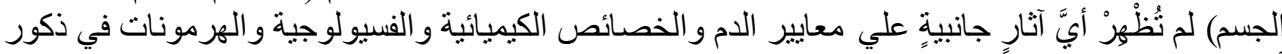

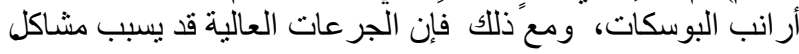

